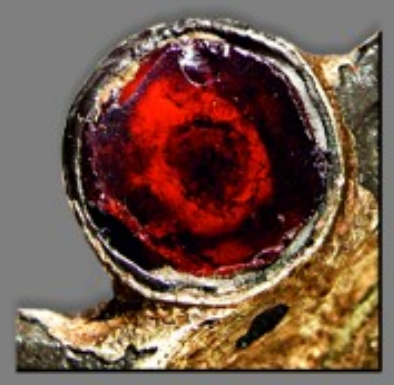

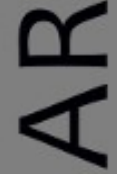

$\sim$

ш
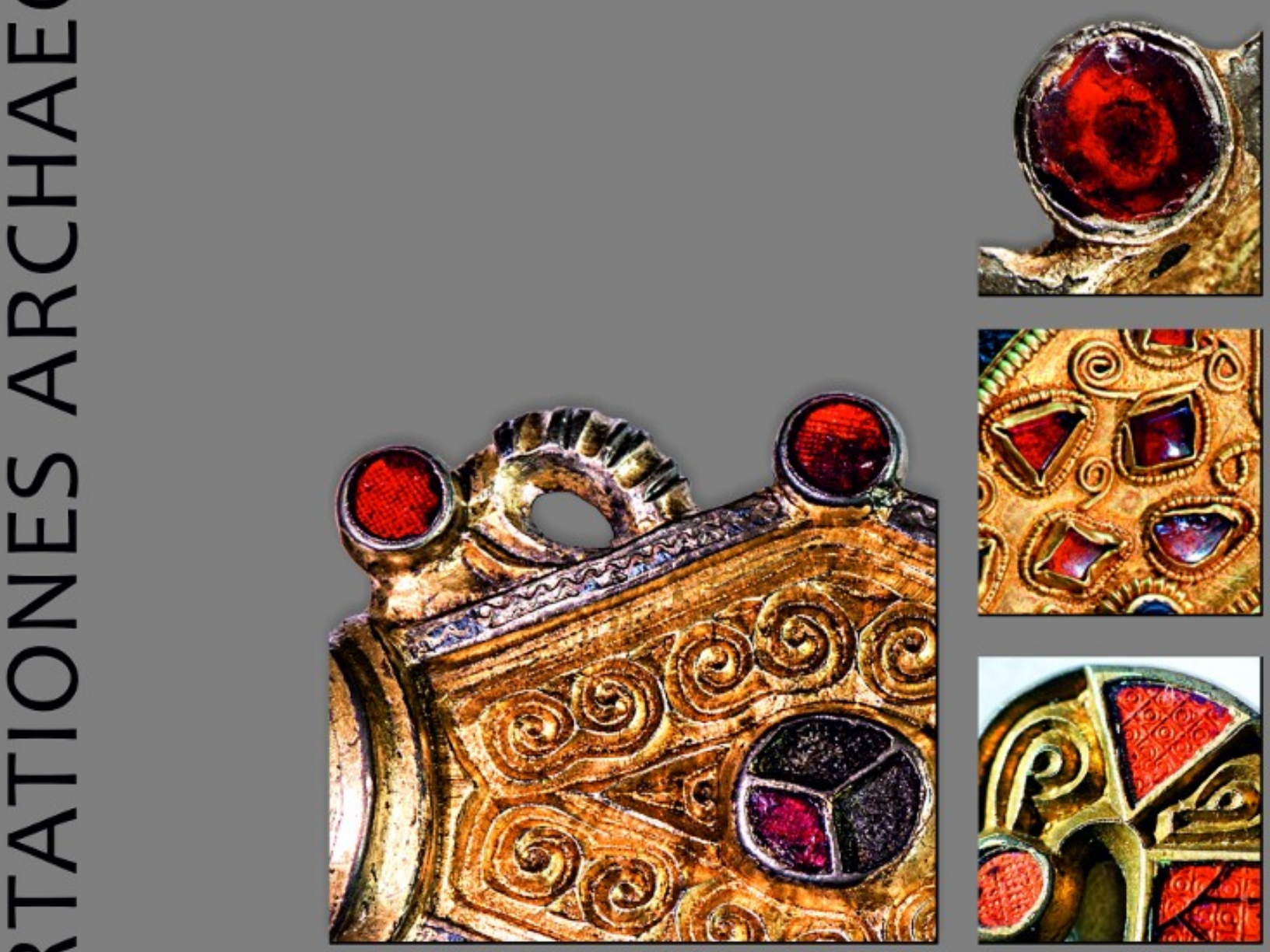

E

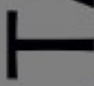

œ

山

n

ก

$\overline{0}$
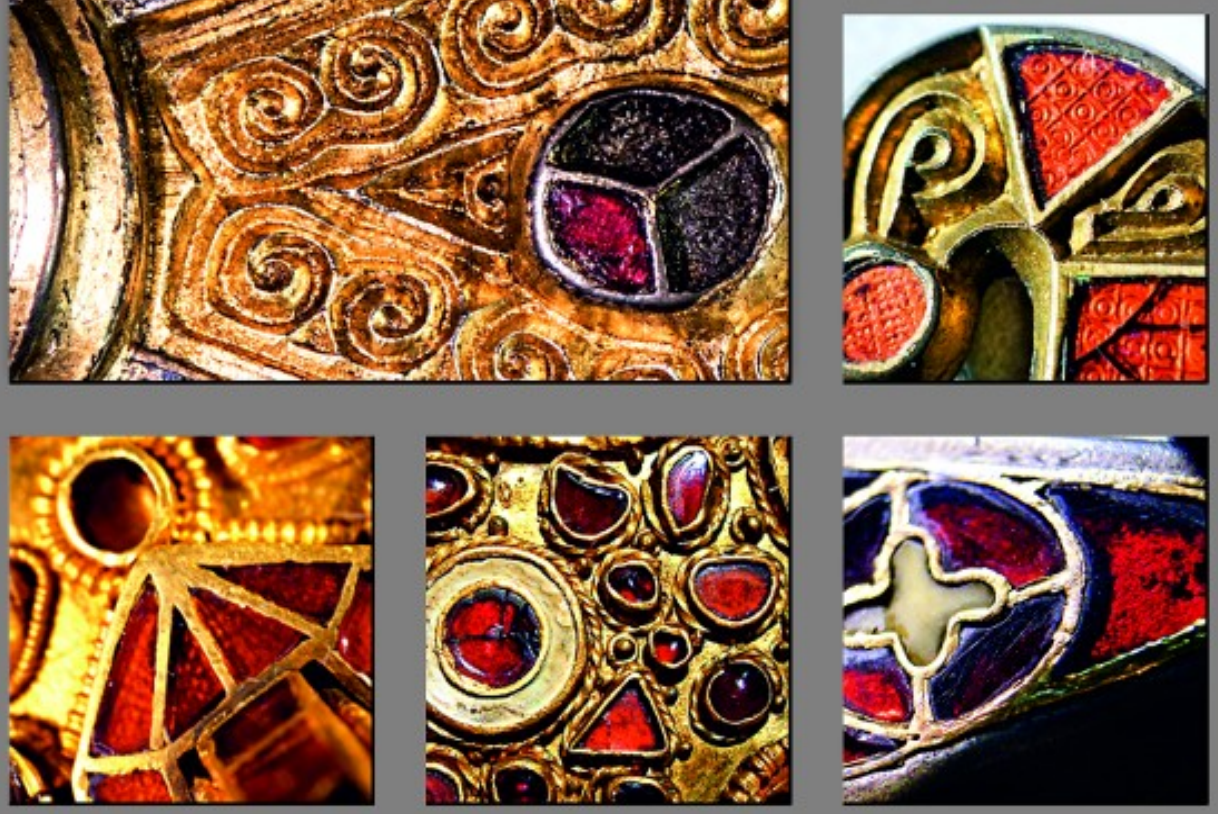

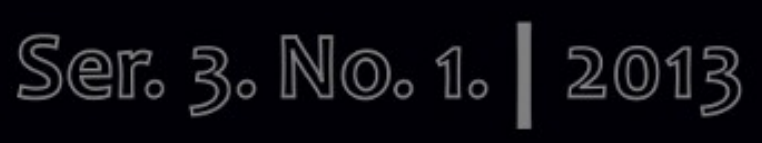




\section{Dissertationes Archaeologicae ex Instituto Archaeologico}

Universitatis de Rolando Eötvös nominatae Ser. 3. No. 1.

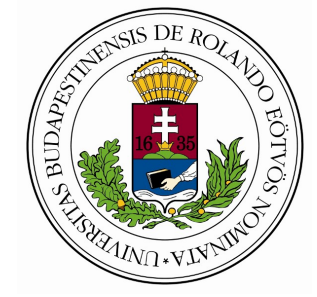

Budapest 2013 
Dissertationes Archaeologicae ex Instituto Archaeologico

Universitatis de Rolando Eötvös nominatae

Ser. 3. No. 1.

Editor-in-chief:

DÁvid BARTUS

Editorial board:

LÁSZLÓ BARTOSIEWICZ

LÁSZLÓ BORHY

ISTVÁN FELD

GÁBOR KALLA

PÁL RACZKY

Miklós SzABÓ

TIVADAR VIDA

Technical editors:

DÁvid BARTuS

GÁBOR VÁCZI

ANDRÁs BöDŐcs

Proofreading:

Zsófia KondÉ

SzILvia SzÖLlősI

Available online at http://dissarch.elte.hu

Contact: dissarch@btk.elte.hu

\section{$\underline{\text { PKP }}$ \\ PUBLIC \\ KNOWLEDGE \\ PROJECT}

(C) Eötvös Loránd University, Institute of Archaeological Sciences

Budapest 2013 


\section{Contents}

\section{Articles}

Melinda TORBÁGYI - István VIDA

The coin hoard of Abasár

Anikó BózsA

21

Roman mirrors from a private collection in the Hungarian National Museum

Lajos JuHÁsz

45

The Biesheim cameo - a reinterpretation

\section{Methods}

Péter CsIPpÁN

$A z$ állatcsont, mint információhordozó leletanyag

Kata DÉvAI

Terminológiai alapfogalmak régészeti korú üvegtárgyak elemzéséhez

Lőrinc TimáR - Zoltán Czajlik - Sándor Puszta - Balázs Holl

$3 D$ reconstructions using GPR data at the Mont Beuvray

\section{FIELD REPORTS}

Zsolt MESTER

Excavation at a new Upper Palaeolithic site of the Eger region (Northern Hungary)

László BORHY - Dávid BARTus - Emese SzÁmadó

Short report on the excavations at Brigetio (Szőny-Vásártér) in 2013

Dénes HulLÁm - Zsófia RÁcz

Report on the participation of the Eötvös Loránd University at the Wielbark Archaeological Field School in Malbork-Wielbark, Poland

Gábor VÁczi - Dávid BARTus

Short report on the excavations at the site Makó - Igási Ugar

Maxim MoRdovin

Short report on the excavations in 2013 of the Department of Hungarian Medieval and Early Modern Archaeology (Eötvös Loránd University, Budapest)

\section{THESIS ABSTRACTS}

Kitti KÖHLER

Biological reconstruction of the Late Neolithic Lengyel Culture 
Cultural connections and interactions of Eastern Transdanubia during the Urnfield period

Orsolya LÁNG

Urban problems in the civil town of Aquincum: the so-called „northern band”

Nikoletta SEY

Questions of bronze workshops in Roman Pannonia

Kata DÉvaI

Glass vessels from Late Roman times found in graves in the Hungarian part of Pannonia

Eszter HORvÁTH

Gemstone and glass inlaid fine metalwork from the Carpathian Basin:

the Hunnic and Early Merovingian Periods

Gergely SzEnTHE

Vegetal ornaments in the Late Avar decorative art

Péter LANGó

Relations between the Carpathian Basin and South East Europe during the 10th century.

The evidence of the minor objects

Ciprián HoRvÁTH

The Cemeteries and Grave Finds of Györ and Moson Counties from the Time

of the Hungarian Conquest and the Early Árpádian Age

András Sófalvi

The border- and self-defence of Szeklers from the Medieval Age till the Age of Principality.

Castles and other defence objects in the settlement history of Udvarhelyszék 


\title{
Cultural connections and interactions of Eastern Transdanubia during the Urnfield period
}

\author{
GÁBOR VÁCZI \\ Institute of Archaeological Sciences \\ Eötvös Loránd University \\ vaczigabor@gmail.com
}

\begin{abstract}
PhD thesis submitted in 2013 to the Archaeology Doctoral Programme, Doctoral School of History, Eötvös Loránd University, Budapest under the supervision of Gábor V. Szabó.
\end{abstract}

Network analysis is one of the fastest growing research areas of our time, which is gaining more and more attention on the fields of mathematics, informatics, biology and sociology when modelling networks of complex connections becomes necessary. The development of mathematical graph theories already had a great effect on North American archaeology and cultural anthropology in the '70s. First their schools researching Mesopotamia and the Mediterranean integrated methods of system analysis into archaeology. Although researches targeting the complex analysis of large archaeological databases have also appeared in Anglo-Saxon and Scandinavian archaeology in the '80s, significant progresses were only made on the field of statistical methods. In the '90s, with the improvement of network editor and analyser programs, applications suitable for examining systems on a complex as well as an elementary level became also available for social sciences. ${ }^{1}$

Meanwhile, Hungarian researchers compiled catalogues of Late Bronz Age artefacts arranged by periods, which prove to be indispensable databases even today, especially for the dating of smaller assemblages and unique finds. ${ }^{2}$ Beside detailed typological analyses, the undocumented finding conditions of depots and hoards do not allow us to draw far-reaching conclusions concerning the ways and reasons of deposition, its role fulfilled in the social and economic spheres, and the relations or mechanisms between changes observable in the social structure and bronze usage.

\section{Goals of the dissertation}

In my dissertation I aimed to analyse the cultural connections of a region that is open in the direction of the Bakony Hills, the Tolna Uplands, the bend of the Danube and the Great Hungarian Plain alike, which means that Late Bronze Age communities once living here must have had great communication opportunities (Fig. 1). Finds collected in the Eastern Transdanubian region - originating from burials, hoards and settlements - cover every phase of the Urnfield period. Bronze items were exclusively involved in the examination. On one hand because of their typological and chronological system that is more specificable than those of ceramic objects. On the other hand because studies dealing with assemblages

1 Brughmans 2010; Furholt 2011; Brughmans 2012; Evans - Rivers - Knapett 2012.

2 Mozsolics 1985; Kőszegi 1988; Mozsolics 2000. 
consisting of bronze artefacts provide detailed, useful sources, whereas in the case of ceramic finds rarely occurs a publication that made the whole material analysable. As a consequence a database with a size and composition appropriate for statistical analyses can be only set up from studies dealing with bronze finds.

The following can be highlighted among the most important questions of the dissertation:

- Are depots and hoards from uncertain sources - which can be almost considered stray finds - suitable for researching the changes of interaction networks and consumption trends?

- Can artefacts of depots and hoards be analysed together with bronze finds of burials and settlements?

- Do all horizons provide a sufficient amount of finds for statistical analyses, and for the analysis of interaction networks?

- If they do, do traditional typochronological frameworks influence the analyses in a negative or positive way, and how do the results of these analyses adjust to the relative chronological frameworks created by deposition horizons?

- What kind of traces did cultural interactions, bronze use and consumption customs left on the material culture?

- Can any similarities or differences be discerned between regions and periods by the intensity of interactions, or the quality and rate of bronze use?

- Can a hierarchy be set up between regions with the help of interaction networks and data concerning bronze use?

- Can the expressions of center - periphery - semiperiphrey often used in theoretical archaeology be applied in the examination of relations between consumption centers?

- Is the significance of different social strata recognizable in the building and maintenance of interaction networks?

- Can vertical social differences be proven on the basis of the results of connection network analyses?

- If they can, are connection networks analysable with the use of information gained through bronze finds in order to differentiate interactions taking place on the level of ordinary households and the armed elite?

\section{Methods applied in the processing of bronze artefacts}

The research began with the periodization and typological classification of a large amount of bronze artefacts. It had to be taken into consideration during the processing of previously published finds that 30-40 years had passed since the publishing of these comprehensive works. Studies written since then changed the chronological position, subtype classification and distribution area of several artefacts. In ceratin cases only the dating or the primary appearance area of an artefact was modified, while in other cases the entire assemblage was classified to a different horizon. 


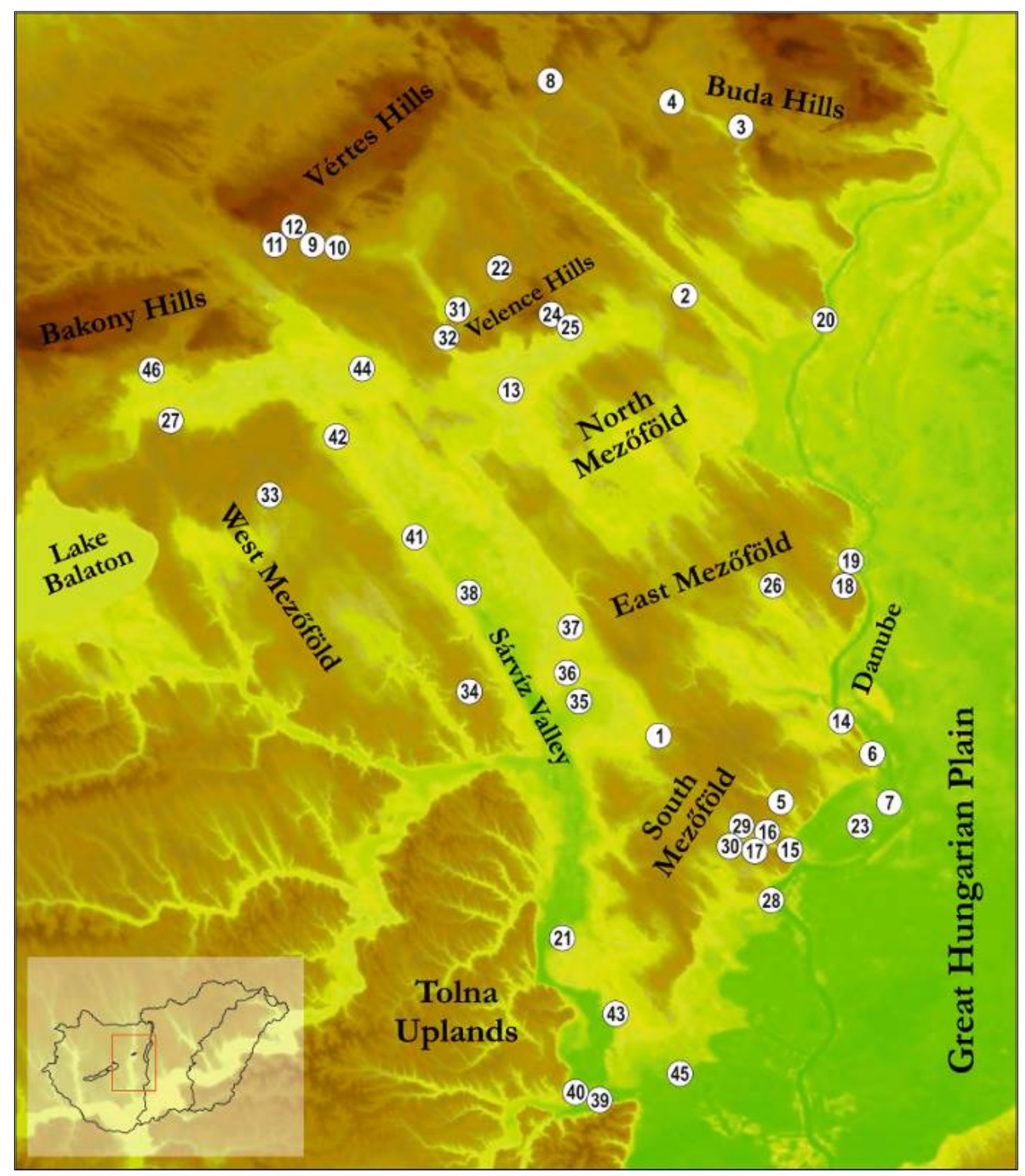

Fig. 1. Geographical distribution of the analyzed finds.

1. Alsószentiván; 2. Baracska-Homokbánya; 3. Biatorbágy; 4. Biatorbágy-Herceghalom; 5. Bölcske-Gyűrűsvölgy; 6. Bölcske-Kéményesi-Duna; 7. Bölcske-Öreg-sziget; 8. Csabdi-Bükköstető; 9. Csákberény-Öreg-tó 1; 10. Csákberény-Öreg-tó 2; 11. Csákberény-Orondpuszta; 12. Csákberény; 13. Dinnyés; 14. Dunaföldvár-Duna; 15. Dunakömlőd; 16. Dunakömlőd-Ürge-hegy; 17. Dunakömlőd-Vörösmalom-völgy; 18. Dunaújváros; 19. Dunaújváros-Duna; 20. Ercsi-Duna; 21. Kajdacs; 22. Lovasberény; 23. Madocsa-Síkhát; 24. Nadap-Jánoshegy; 25. Nadap-Kőbánya; 26. Nagyvenyim; 27. Ösi-Bírórét; 28. Paks-Duna; 29. Paks-Gyapa-Vörösmalom-völgy; 30. PaksGyapa-Külső-dűlő; 31. Pátka-Belterület; 32. Pátka-Kőrakáspuszta; 33. Polgárdi; 34. Pusztaegres-Pusztahatvan; 35. Sárbogárd-Rétszilas; 36. Sárbogárd-Sárszentmiklós; 37. Sárbogárd-Tringer-tanya; 38. Sárvíz-csatorna; 39. Sióagárd-Leányvár; 40. Sióagárd-Sárvíz-part; 41. Soponya-Nagyláng-Kispuszta; 42. Szabadbattyán-Csíkvári patak; 43. Szedres; 44. Székesfehérvár-Szeder utca; 45. Tolna-Mözs; 46. Várpalota. 
Beside the known finds, the analysis of numerous unpublished or believed to be lost assemblages was also carried out, among which unique finds, depots and hoards of different sizes, grave goods, and artefacts found with the use of metal detector occurred in equal proportion.

The process of the primary, namely the typochronological and territorial characterisation is completed with unconstrained binary seriation. Mainly the chronological classification of depot finds made seriation necessary, and the observable divergences and contradictions related to the division of deposition horizons. Database of the analyses was provided by more than five hundred Central European depots and hoards of the Urnfield period. Instead of traditional deposition horizons, seriation divided the Urnfield period into seven chronological phases (Fig. 2). Overlappings symultaneous with the original chronological division and including the shift of the two horizons appeared alike. Short sections indicate transitional periods, such as the $\mathrm{HaA} 2$ and the HaB2/3 periods, which however should not be necessarily examined as independent horizons. Sections indicating a longer time interval are the $\mathrm{BrD}-\mathrm{HaA} 1$ and the $\mathrm{HaA} 2-\mathrm{HaB} 1$ periods, which outline long-running developmental processes of the Late Bronze Age metallurgy and material culture. The above listed transitional phases as well as the longer overlappings can be also demonstrated through correspondence analysis, which takes quantitative data into account too (Fig. 3). With the measurement of quantitative data the $\mathrm{HaA} 2$ and the $\mathrm{HaB} 2 / 3$ periods - thus the transitional nature of the Gyermely and Románd horizons - appear even more firmly. The reason for this is that the majority of assemblages belong to the $\mathrm{HaB} 1$ period, overlapping the $\mathrm{HaA} 2-\mathrm{HaB} 1$ or $\mathrm{HaB} 1-\mathrm{HaB} 2 / 3$ periods, and there are only a few depots or hoards which can be dated to the $\mathrm{HaA} 2$ or the $\mathrm{HaB} 2 / 3$ periods alone.

During the examinations concerning the composition of depots and hoards I compared the frequency of artefacts as components with the occurrence rate of artefact types related to each other. The determination of the principle component of each period was followed by correspondence analysis testing the most frequent common occurrences together with quantitative values. The two methods together did not only reveal the order of components, but also indicated the occurrence and quantitative rate of other items compared to the principle compontent on a regional and chronological level. ${ }^{3}$

On the course of principle component analyses the lack of representative quantity often became a distorting factor. When analysing assemblages with few pieces and types of artefacts, or periods providing only a few depots, the number of finds is underrepresented for the number of components, and therefore the results did not show real proportions. In contrast, data of periods and regions containing larger series and representing a wider spectrum of types are more suitable for modelling changes and trends related to compositions by periods. The examination of the principle components of each horizon displays the rate of dominance of artefact types primarily determining depot compositions, and the quality of bronze objects available to the individual or community participating in the accumulation, deposition or burial. However, it does not indicate the combination of artefacts of deposited assemblages organized in a functional order.

3 Drennan 2009, 299-300; ŠabatovÁ 2010, 111. 


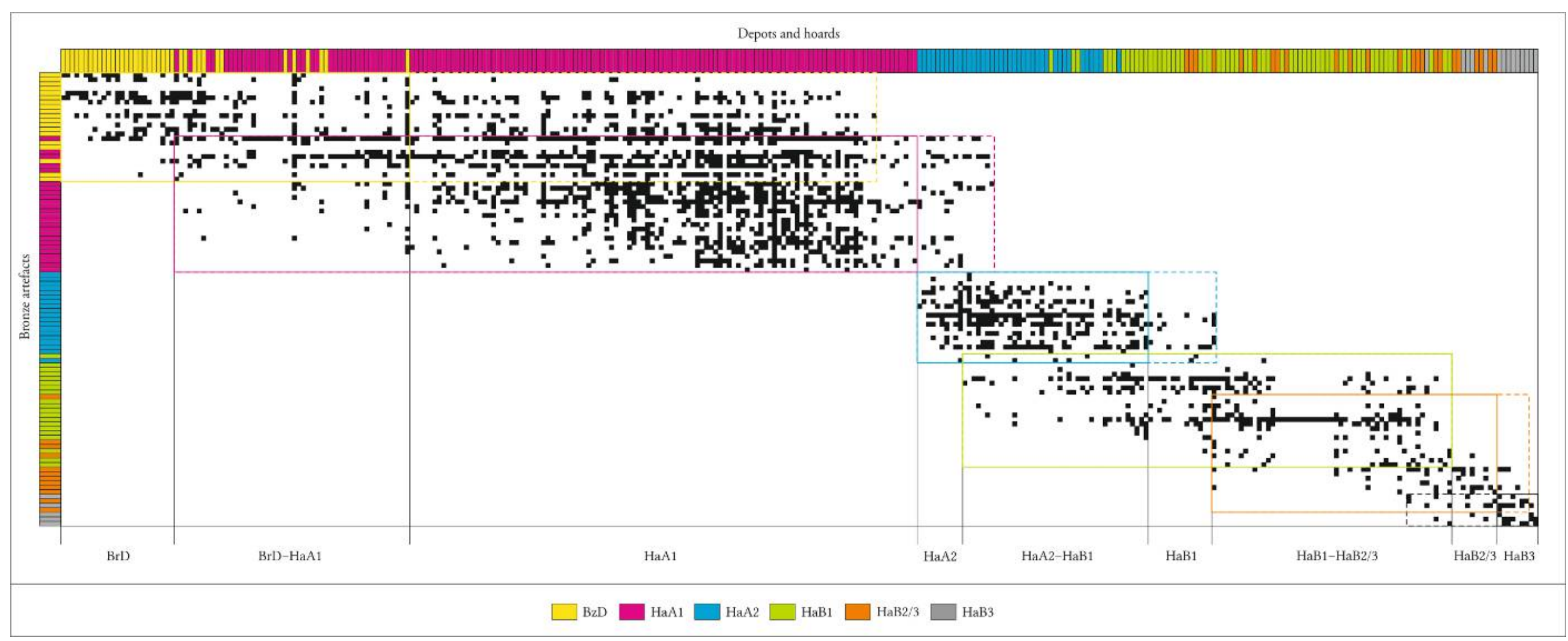

Fig. 2. Chronological classification of depot finds with unconstrained binary seriation. 


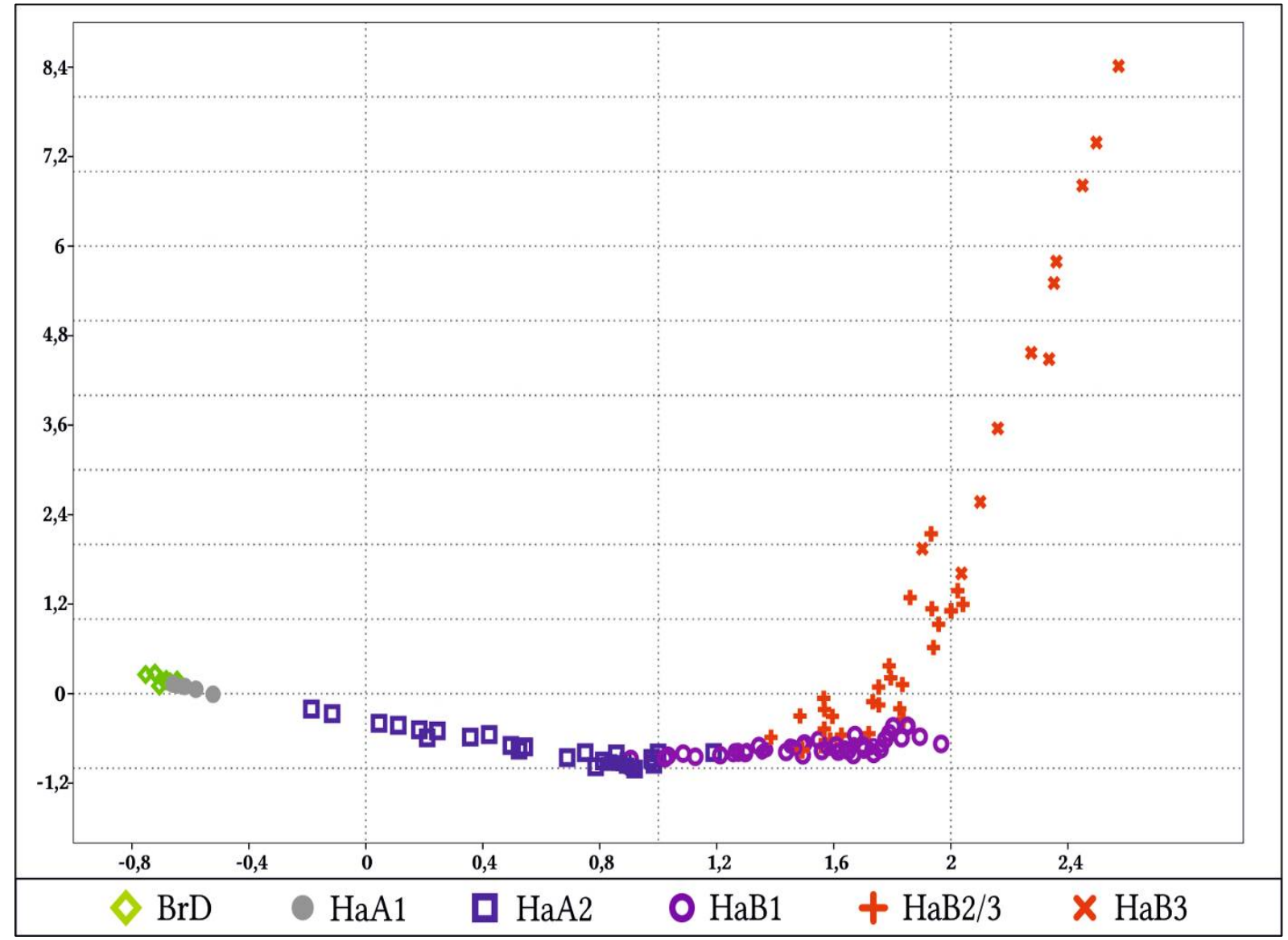

Fig. 3 .Correspondence analysis of depots and hoards of Eastern Urnfield communities.

With the use of correspondence analysis, taking frequency and common occurrence of the artefacts into account, a data series is created that indicates functionally related components most often deponated together. During the analysis of a certain period the compontents of functional groups become visible ${ }^{4}$ (Fig. 4). On the other hand, in case more groups - different in artefact types as well as their quality - can be differentiated within a period, their positions related to each other can be also described. On the basis of the analysis of functional groups divided by horizons and regions find sets can be outlined, which can vary by periods and regions alike. In the periods distincted by deposition horizons functional sets of finds can be different even by regions. Social, economic, or technological conditions can be revealed behind the differences, although the (often manipulated) role fulfilled by an artefact or a group of artefacts during the deposition or the burial did not necessarily correspond to their status fulfilled in everyday material culture.

In the analyses taking the function of certain artefacts and the principle component or composition by combination groups of assemblages into account the artefacts appear in sets divided by types and periods. Beside these, the finds of assemblages carry important information as parts of Bronze Age households having a (life)time of use, and as reusable raw materials. Within their lifetime that can be described as the circulation of bronze, the stages of semi-finished, unused, used up, and prepared for smelting/casting can be distinguished. The rate of possession, accumulation and wasting is an important factor in the modelling of

4 FALKenstein 2011, 81-82; Furholt 2011, 262-263. 
the social and economic environment that influences the character of producing, using and moving (exchange/gifting) of bronze items. The actual state of a bronze artefact fixed when substracted from use (burial, deposition, waste production) indicates the social position, economic system and technological development of a given individual or household. ${ }^{5}$

Taking their external features, distribution area, stages of use, and their role fulfilled during symbolic events into consideration, as well as the the most frequent combinations or functional groups of assemblages, artefacts are suitable for the reconstruction of relations between individuals or communities. ${ }^{6}$ The methods and basic concepts of the research of social networks can be mainly applied to network analyses used for archaeological purposes, however, due to the limited knowledge regarding features of elements building up the system the methodology of social network analysis can be only used partially, which is suitable for modelling the form, direction, as well as the intensity of interactions between active elements.

Network analyses used for archaeological purposes cannot be considered direct social analyses, since regions of the examination have to be defined in every case, depending on whether the connection systems of the mental or material sphere are being analysed. On a theoretical basis it is possible to define the individual, means, reason/purpose, time and place of the interaction, but the value of information of archaeological material strongly cuts the line of the above listed criteria. ${ }^{7}$ Apart from the means of interactions, the time and place can be determined precisely in a prehistoric approach, however, the reasons or purposes of the establishment and maintenance of relations between past individuals and societies are unknown.

In an ideal case the acting part within a network means individuals or households in an ar chaeological context, which can be linked to objects, and thus every tie marks an individual and an object at the same time. Instead - due to the value of information of archaeological finds - objects act as subjects of the ties, and we can conclude the individuals or communities establishing the networks from the character of the ties.

The directions and the subordinate or ordinate relationships cannot be determined by qualitative and quantitative indicatorsof the artefacts. Based on the here listed criteria the database constructed by the examined finds is only appropriate for the modelling of networks consisting of dichotomous ties. The connection network between the examined region and the neighbouring regions can be modelled according to archaeological criteria with the georeferated version of graphs independent of spatial position, consisting of nodes, bridges and small worlds. Levels of the analyses of relationships between individuals, households, micro- and supraregions can be differentiated, however, taking the source value of the material involved in the study into account, only the analysis of interaction networks of micro- and supraregional levels is possible. With the help of georeferated models centrality and intensity degree, as well as the extent of networks become measurable, on the basis of which the studied region can be divided to communication and consumption zones. ${ }^{8}$

5 Gosden - MARshall 1999, 169-170; ŢÂRLEA 2008, 68-69.

6 SOSNA ET AL. 2013, 60-64.

7 HOREJS 2009, 203.

8 MunSON - MACRI 2009, 425. 


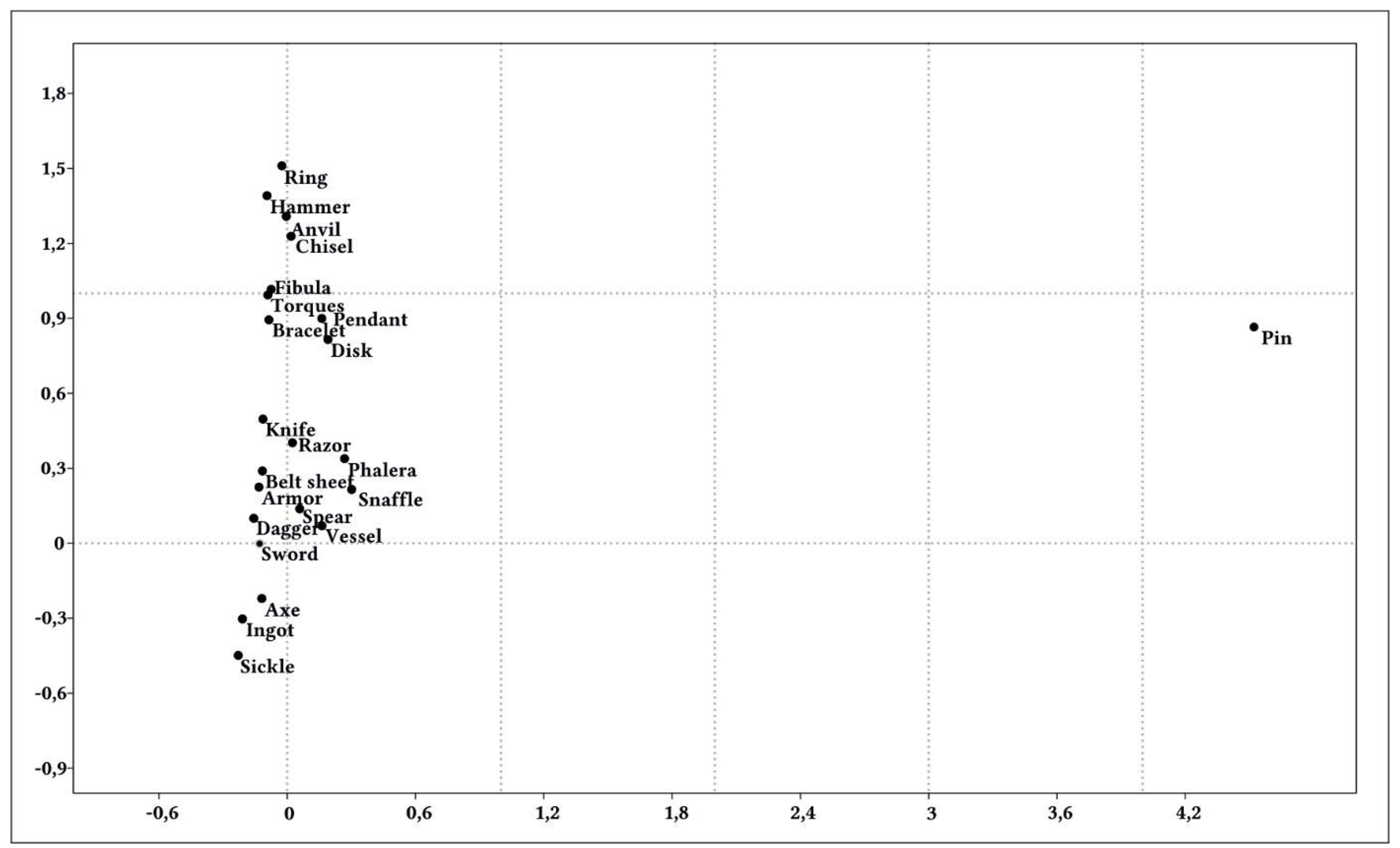

Fig. 4. Components of the functional groups of the Kurd period (HaA1). 
After the determination of consumption zones regions involving an outstanding number of participants and forming a closed system can be distinguished, around which elements or smaller groups of elements are unevenly spread, but always bound to a central region. End points can be found on the periphery of the system, which connect to the center of the sys tem or to an element in its immediate vicinity with long-distance ties. The relation of the listed network elements is very similar to the division "center-semiperiphery-periphery" or with other words "center-periphery-marginal zone" often used in theoretical archaeology, however, it is not equal with them. The reason is that the type, size and localization of the examined sites, the immediate and broader settlement network, the composition of the material, the type and amount of artefacts with indicator function, as well as the external and internal qualities referring to the dislocation of the finds should be all taken into consideration. Contrary to that, examined finds only allow us the analysis of the composition, the qualitative and quantitative indicators of assemblages, furthermore the determination of artefacts with indicator function, and the outlining of their distribution area.

The primarily, secondary and occasional zones distinguished on the basis of bronze circulation and consumption ${ }^{10}$ cannot be completely identified with the expressions of center, semiperiphery and periphery, since the social and economic differences related to consumption could only be determined relying on the finds. The composition of bronze find material - especially in the case of depots and grave goods - is strongly influenced by the spiritual background; however, this manipulated state is not necessarily equal to the real social and economic system. In the analyzed region the zones of bronze use and consumption can be ranked by the degree of openness to innovation, the presence of composite production and decoration technologies, and the number of artefacts produced in series.

\section{Results of secondary (statistical) characterization}

The primarily characterization of the finds was followed by analyses separated by periods, based on common occurrence combinations and use trends, which gained significance during the examination of interactions organized on the level of individuals, households or communities.

On the course of the secondary characterization of the BrD period finds buttons and sickles could be determined as first and second components, however, it had to be taken into consideration for the interpretation of data series that the disproportionately high number of small, easily fragmentizing sheet buttons and sickle blades distracts real values. After this correction the series of pendants, bracelets and needles, and finally of swords and spearheads can be set up.Weapon and ornament sets satisfying representational needs undoubtedly dominate among the objects, while the number of tools is very low. The deposition practices of the late Tumulus-early Urnfield periods can be compared to the lavishing and representing character of burials, and accordingly, bronze tools and semifinished products did not gain representational role during these events.

According to the results of common occurrence analysis the artefacts of the BrD-aged assemblages of the eastern Urnfield circle are organized around a closer functional group. 
Contrary to the set consisting of weapons, vessels and belt sheets, ornaments and tools do not form functionally distinguishable functional groups. The common occurrence indicators of the Northeastern Hungarian and Eastern Slovakian depots refer to the incipient clustering of the artefact types of weapons, ornaments and tools. Functional groups are not closed, since some artefact types are under- or overrepresented. On the whole, the Upper Tisza region and Eastern Slovakian weapon and ornament sets among the BrD period finds refer to the conscious and representative manipulation of depot compositions, while the separation of the functional groups of weapons, ornaments and tools within the eastern Urnfield circle outlines the appearance of a new bronze use (consumption) trend.

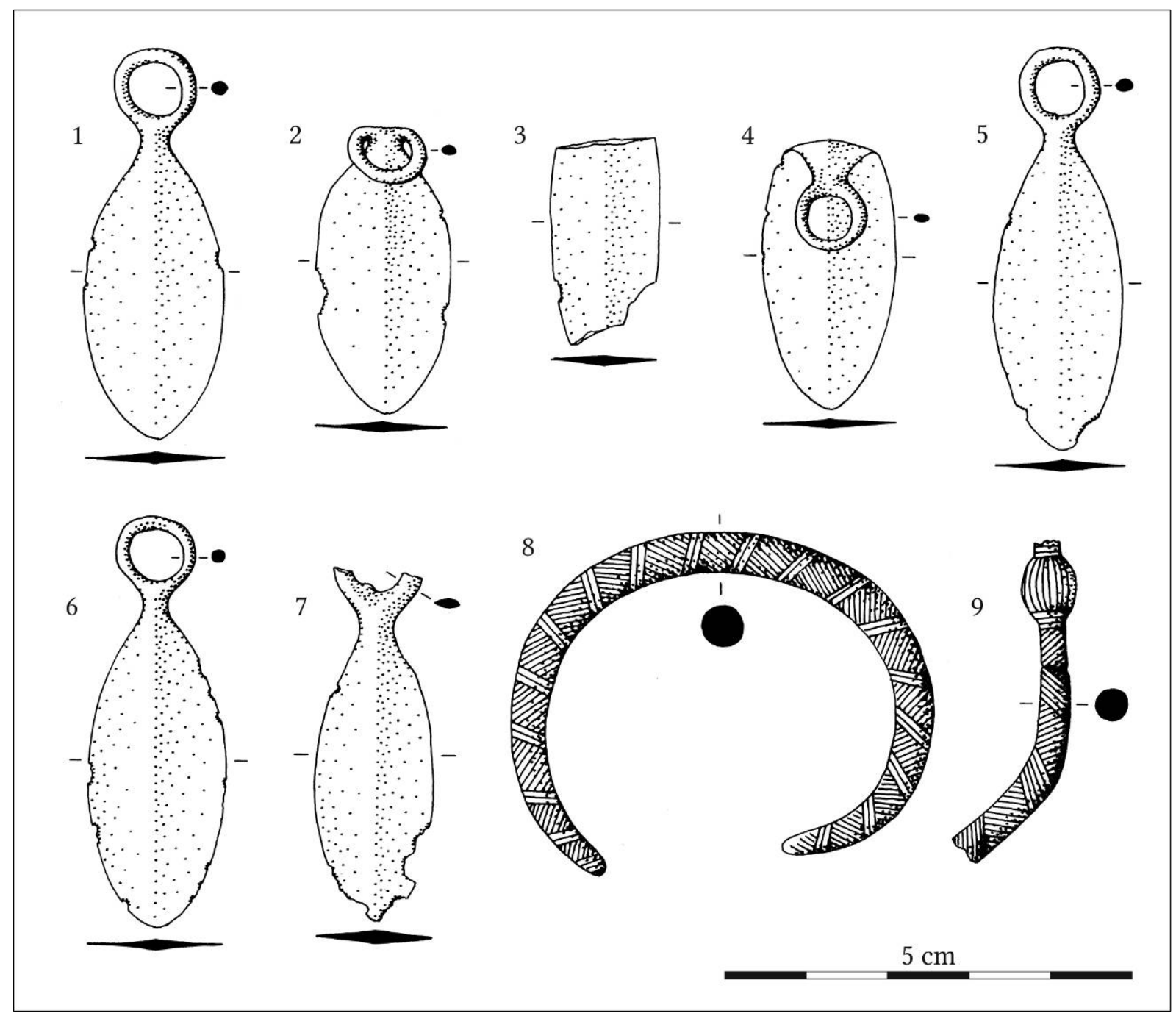

Fig. 5. The hoard of Dunakömlőd-Ürge-hegy.

Transdanubian characteristics of bronze use cannot be analyzed from the perspective of deposition customs in the formation stage of the Urnfield culture, since only the data of the Dunakömlöd-Ürge-hegy hoard are available (Fig. 5). The intact condition of the hoard, the absence of Transdanubian depot finds, and the mortuary practices of the period indicate that the representational value of intact artefacts must have been significant in grave offerings as well as deposition. The lack of tool deposition characteristic of the early Urnfield communities of the Moravian basin indicates that the Bakony region and its neighbouring areas 
formed a closed interaction system, in which new weapons and characteristic customs "quickly" appeared. However, they did not follow new trends concerning deposition and bronze use methods observable in the Eastern Alpine region.

Numerous axes and intact sickles dominate the composition of HaA1 period depots of the Transdanubian finds, but with regard to the number of pieces, strongly fragmentizing sheet bracelets and saw blades distort the order of principle components. On the course of the functional analysis, bronze items of the period got arranged in three closed groups; the groups of weapons, tools and ornaments. The closed group of the great number of weapons and bronze sheet artefacts (armature, vessels) refers to the great effect of the armed elite on deposition. The clustering of tools indicates two possible deposition trends in Transdanubia: tools accumulated in a large number reflect the economic power of the elite, which can be represented even in the everyday life, while smaller sets can be connected to symbolic events organized on the level of ordinary households.

With a surge in growth in the number of depots the differentiation of several qualitative and quantitative categories within the composition of depots became possible. In the eastern Urnfield circle three subtypes of deposition customs can be distinguished: unique finds, small depots mainly including tools, and large, lavishing assemblages consisting of weapon and vessel sets, as well as numerous fragmentary artefacts. Different bronze use customs can be ravealed behind the wave of deposition beginning at the "same time" in Transdanubia, in the Drava-Sava interfluve, and by the upper reaches of the Drava River.

The number of ingots and semi-finished products decreases southwards, and they do not appear in the deposited assemblages of the communities that lived by the Sava. Heavy, intact artefacts received primary role during the symbolic and representational events of every region, however, the lack of intact swords - in Eastern and Southern Transdanubian, as well as Southland (present-day North-Croatia) depots - indicate that the elite had a great effect on the economic system, as well as on deposition practices. The frequent deposition of tools broken during use and loosing their function, and of small fragments suitable for reusing, is typical of the whole eastern Urnfield culture, which indicates the increasing role of bronze as raw material. In the eastern Urnfield circle the accumulation of raw material must have been the most common form of representation. It is typical of smaller-sized assemblages that they consist of tools and lack weapons, thus they can be primarily linked to votive or profane occasions of household units. In larger assemblages with hundreds of finds the economic power and social position of the depositing individual or community was emphasized with offensive and defensive weapons, as well as tool and vessel sets.

Later on, the composition of the HaA2 period assemblages was determined by a great number of ingots and semi-finished products. During the Gyermely horizon the deposition order that had developed during the Kurd horizon completely disappeared in Transdanubia. The arrangement of artefacts in functional groups was not characteristic any more; rather the accumulation of great amounts of bronze received representational role in this transitional period. At the same time the development of a new social and economic structure could be in the background of the closed functional sets of weapons and ornaments. Accessible and accumulatable bronze received a growing significance in the Transdanubian bronze circulation. This phenomenon is also reflected in Eastern Transdanubia, where the composition of heavy depots was determined by ingots and semi-finished products, though the number of 
intact items produced with composite technology was very low. Beside the accumulation of reusable semi-finished products and small fragments, the narrowing of the spectrum of types and the quality deterioration of raw materials also imply to a crisis of bronze circulation or the absence of a social group that would have been able to arrange supply.

It indicates the possibility of the conflation of the $\mathrm{HaA} 2$ and $\mathrm{HaB} 1$ periods that in the $\mathrm{HaB} 1$ period ingots and hoop earrings yet appeared among the principle components in primary position, thus, concerning composition, there is no such a great discontinuity between the bronze crafting of the two periods, as it was observable in the case of the change of the $\mathrm{HaA} 1$ and $\mathrm{HaA} 2$ periods. In the Transdanubian region the intensity of deposition decreased; only two greater deposition zones remained in the vicinity of the primarily examined area: the Great Hungarian Plain and the Moravian Basin. At the same time the demand for representation further increased within the circle of armed individuals, which had an effect even on bronze use and deposition. With the Gáva culture gaining ground a double trend developed during the Hajdúböszörmény horizon. On one hand depots consisting of weapon and vessel sets appeared, and on the other hand the practice of depositing used-up artefacts and small fragments in large quantities remained. The two deposition practices indicate that beside the representation of the armed elite symbolic events organized on the level of households also appeared within the life of communities living in the Great Hungarian Plain. On the basis of the characteristics of the East Transdanubian region, the Sárbogárd-Sárszentmiklós ${ }^{11}$ and Sióagárd-Leányvár (Fig. 6-7) hoards referring to bronze use, they can be associated with assemblages of the Great Hungarian Plain. Consequently, during the HaB1 period cultural influences of the communities living in the Great Hungarian Plain could already have an effect on the economic system and spiritual life of the households of the Mezőföld.

Due to the low number of analyzible finds and thus components the examination of the $\mathrm{HaB} 2 / 3$ period is very difficult. Some assemblages presented a strikingly high number by pieces or types, which alone distorted the whole data series. In the analysis of functional groups the definite separation of the groups of weapons, ornaments and tools indicates that - similarly to the HaA1 period - deposition took place through conscious manipulation, satisfying representational needs, and within controlled frameworks. This social and economic development points towards the Hallstatt culture, and it can be considered part of a process ending the Urnfield period.

Because of its transitional nature similar to HaA2 period, only a few finds can be dated to the HaB2/3 period, which can be listed in two deposition zones: beside Northwest Transdanubia, the Moravian basin can be determined as a narrower zone. In the case of Transdanubia no uniform bronze use or trends can be observed: all bronze hoards showed unique rates according to quantity and composition alike, therefore the underrepresented quantity of artefacts did not make the material suitable for the analysis of bronze use practices.

Both the composition of the different Prescythian period assemblages and the low number of hoards meant a distorting factor, which was also visible in the principle compontent analysis. The Prescythian material culture appearing during the HaB3 period reflects a spiritual background different from that of the Urnfield period in deposition practices and depot composition. However, the definitely distinct functional groups of weapons and ornaments indicate that representation was part of the social and spiritual life of the armed elite exclusively. 


\section{Cultural connections and interactions of Eastern Transdanubia during the Urnfield period}

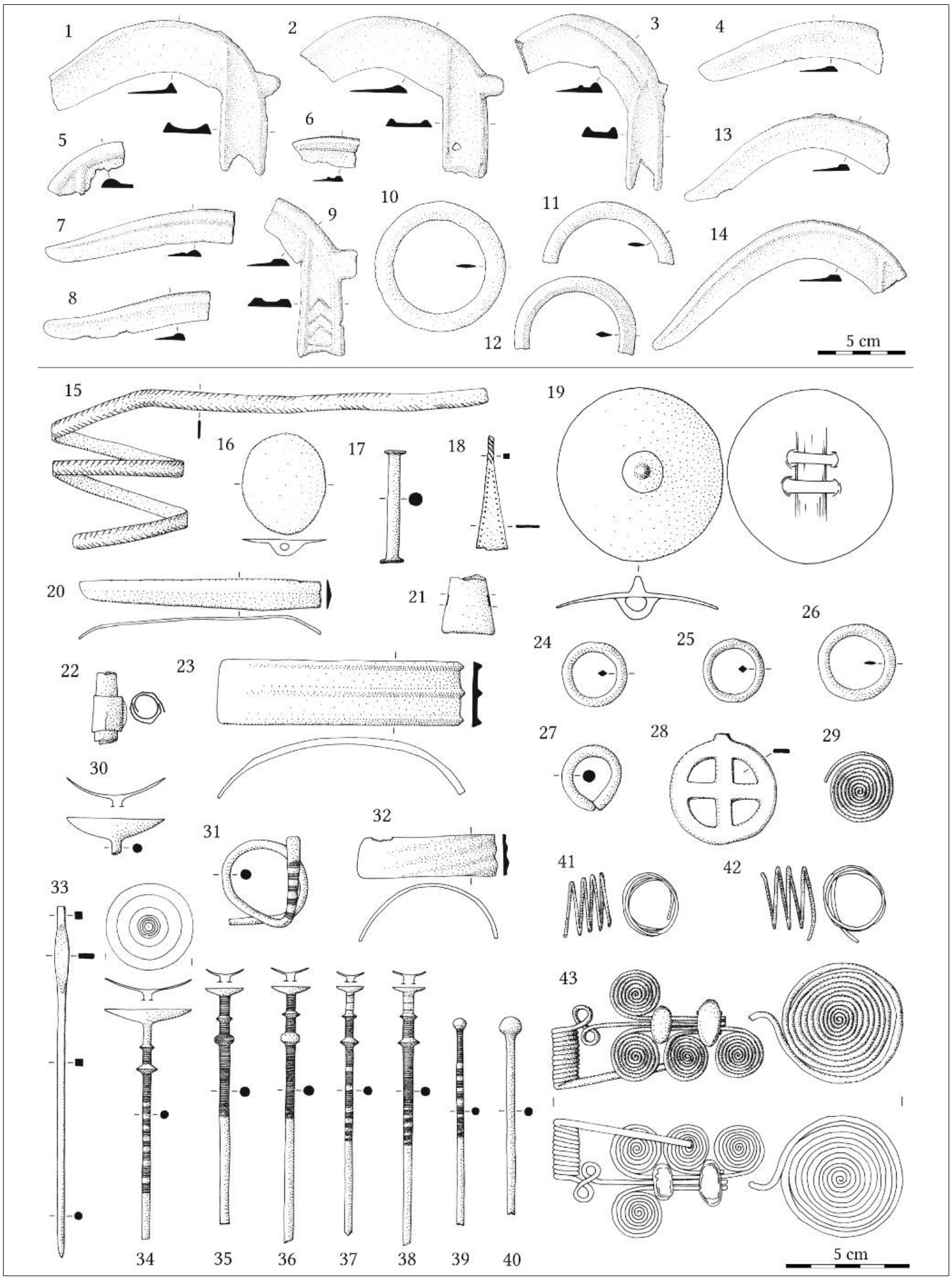

Fig. 6. The bronze depot of Sióagárd-Leányvár. 

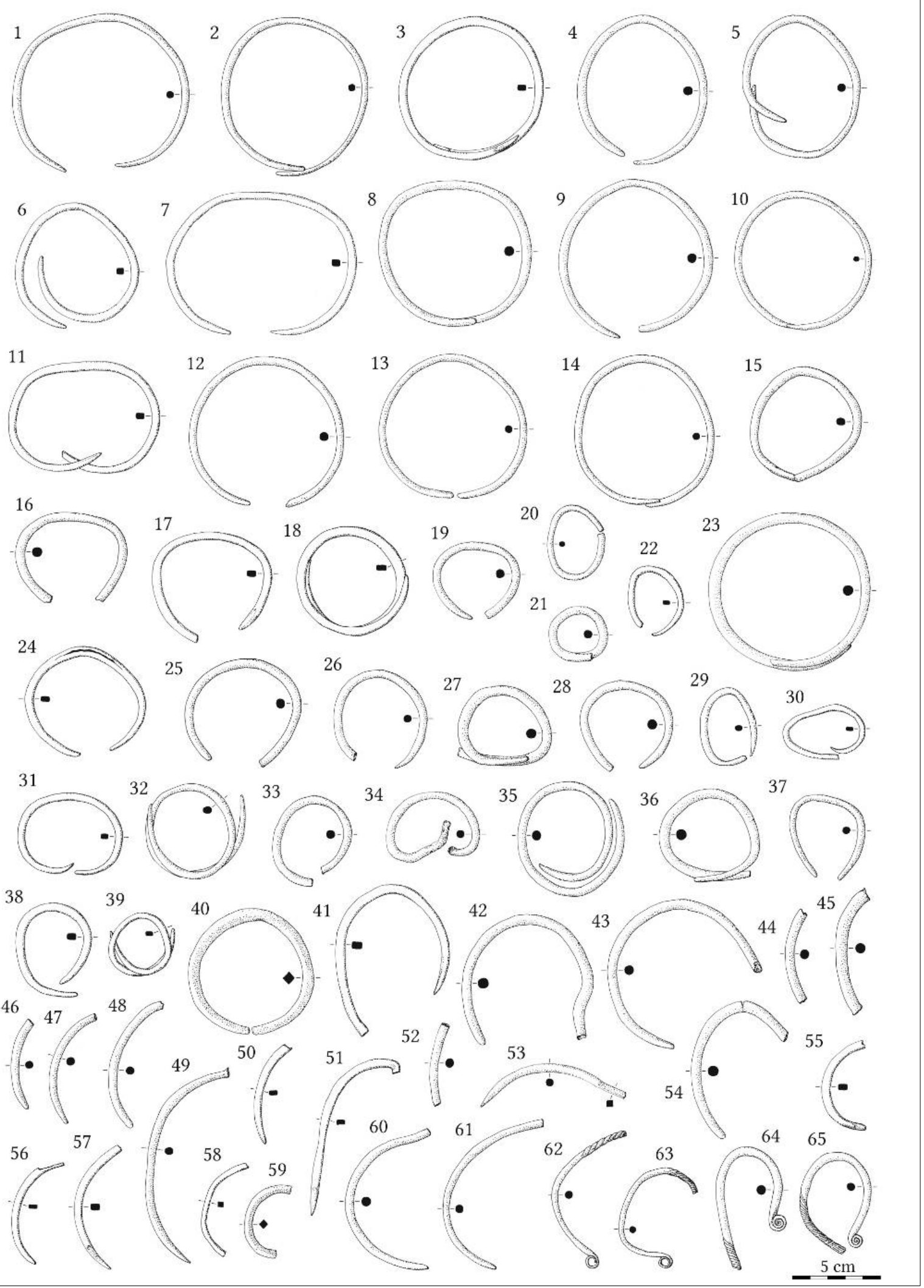

Fig. 7. The bronze depot of Sióagárd-Leányvár. 


\section{Results of the structural analysis of connection networks}

The extent, structure and elements of interaction networks refer to the degree of organization, economic system and the power of communities, on the basis of which the wider social, economic and spiritual changes influencing Late Bronze Age connection systems become known.

The structure of the communication system modellable by the ornaments of the Late Tumulus-Early Urnfield period can be only examined on the basis of the scattering of material intensive artefacts with complex surface treatment/decoration. The ornaments found among Eastern Transdanubian grave goods outline a long-distance interaction zone reaching the Moravian basin and the Eastern Alpine region (Fig. 8). In the case of weapon distribution, networks connected by long-distance bridges are the most frequent among structured graphs. The role of Eastern Transdanubia is negligible in terms of connection systems, since the cultural effects arriving from Bakony region communities are rather decisive. Consequently, there is a great possibility that interactions observable between the Eastern Alpine and the Transdanubian zones reached the communities of the Mezőföld through bridges of the Bakony region.

The high number and more complex type-spectrum of the Kurd horizon depot finds allowed a detailed connection alanysis, which was based on primary characterization and analyses of the functional groups of artefacts (Fig. 9). The uniform distribution of heavy tools refers to intense communication, which is also confirmed by the complex system of connection bridges. The primary distribution area of tools is equal to the spreading of small worlds modellable by weapons and bronze vessels, thus the accumulation of everyday items in great number belongs to the economic environment of the armed elite. The short links of the graph analyzing the ornaments of the period reveal that customs related to ornaments were organized on a microregional level and among households, and this system rather followed the network of tools than weapons. Long-distance, multipart gifting or exchange involving prestige goods can be demonstrated by the shifting of sheet products. This network is complex, however, farther from the South Transdanubian primary manufacturing and consumption area the number of bronze vessels and defensive weapons decreases, which phenomenon refers to the presence of free-lance exchange/gifting.

The two-level interaction network which had been established during the previous period and had both organized on the level of households and the armed elite, collapsed during the HaA2 period in the South Transdanubian region, and reorganized in Northeast Transdanubia (Fig. 10). The connection network center of the Gyermely period - that was separated as an independent horizon, although it can be rather considered as a transitional phase - was located on the area of the Vértes, Gerecse and Buda Hills. Small worlds developing in the zones of the Keszthely and Kőszeg Hills indicate that the residents who populated the highaltitude settlements in the HaA2 period actively took part in the cultural interactions of Transdanubia since the earliest period. The North Mezöföld sites can be connected to the Northeast Transdanubian region, however, the inner links of the small world with increased centrality do not imply to an advanced degree of organisation. The structure of the network models extended to Transdanubia did also not reflect such a complex system in the case of tools and ornaments as the connection network of the previous horizon. The negative results 
of the functional group analysis of artefacts also affirm the observation that interactions of the HaA2 period connected to bronze artefacts took place in a less organized way than during the Kurd horizon. The significant rate of long-distance as well as occasional links is typical of the connection network of tools and ornaments. At the same time the Great Hungarian Plain branch of the graph established by tools showed the picture of a system that is rather typical of the initial phase of the small world formation. This phenomenon can be explained by the effect on bronze use caused by the Gáva culture that appeared in the Great Hungarian Plain during the HaA2 period.

The degeneration of the connection network system during the HaA2 period continued in Eastern Transdanubia during the HaB1 period (Fig. 11). Among the possible ways of representation deposition did nearly not receive as much emphasis as in the earlier periods of the Urnfield culture. In representation the building, possession and maintenance of fortifications became more significant than the accumulation of bronze. As a consequence, the circulation and shifting of bronze is more difficult to follow, and thus the elements and links forming the graphs cannot be modelled by the help of bronze artefacts. Eastern Transdanubian deposition practices of the period refer to the presence of cultural and economic connections maintained with communities of the Great Hungarian Plain. Tool and weapon types of the Great Hungarian Plain, as well as their poor quality copies indicate the strong influence of the Gáva culture. On the basis of graphs the periphery of the range of this influence could run in the area of the Mezöföld and the bend of the Danube. With regard to ornaments, the interaction network of the communities of the Mezőföld is connected to the Moravian Basin with several links. Long links of the network and small wordls reconstructed in the regions of Moravia and the Great Hungarian Plain indicate that Eastern Transdanubian communities were only secondary participants of these interactions, the structure of which can be best analyzed trhough swords. The exchange or gifting network of swords provided the possibility of communication enabling the quick distribution of tools and ornaments, and thus manufacturing technologies, as well as customs concerning their use and wearing.

The Eastern Transdanubian finds of the $\mathrm{HaB} 2 / 3$ period are not suitable for a complex network analysis, since beside the narrow spectrum of types the number of finds is also very low (Fig. 12). The only thing that could be determined is that practices concerning costume and tool manufacturing probably reached the communities of the Mezőföld through a communication channel running along the Danube Valley. These practices appeared first at the increased centrality sites of the small worlds evolving in the Eastern Alpine, Moravian and Waldviertel regions during the last period of the Urnfield culture.

The connection system of the Prescythian period of the Mezőföld analyzable by bronze artefacts is connected to communities settling in along the Danube and bringing eastern material culture (Fig. 13). Weapons and trappings prove that this interaction network consisted of long-distance and occasional links, and the presence of small worlds with increased centrality typical of the Urnfield period cannot be revealed. Rather the development of a network covering a large area in a short time can be observed in the Mezöföld and the Great Hungarian Plain, the secondary interaction zone of which reached even the Eastern Alpine region. Bronze artefacts typical of the Urnfield culture no longer occurred among the Eastern Transdanubian finds of the Prescythian period dated to the HaB3 period. 


\section{Changes in the relation of bronze use and the armed elite}

Based on the joint analysis of the common occurrence rates of secondary characterization, characteristics of data concerning bronze use and network structures, central consumption zones can be distinguished, around which secondary consumption zones and farther, incidental or occurrent consumers can be found. The bronze use practices of each zone and the interactions related to bronze use reflect the social structure and economic system of a given community. In the case of horizons containing an appropriate number and composition of finds, bronze use practices organized on the level of households and the armed elite can be analyzed through everyday and symbolic interactions. ${ }^{12}$

Among the Transdanubian assemblages of the BrD period the sites of communities building fortified settlements and tumulus burials in the Bakony region mark a primary consumption zone. In the case of weapons the effects of the North Hungarian consumption center are significant, and its exchange or gifting network can be followed as far as the Moravian basin. In spite of long-distance communication and the shift of some artefact types, deposition and bronze use practices typical of the Moravian or North Hungarian regions do not appear in the Mezőföld. Weapons and ornaments received a unique role exclusively; therefore armament can be considered the most frequent form of increasing prestige during the BrD period of the Late Bronze Age. At the same time the economic power of the armed elite did not yet reach the level that would have been essential and necessary for supporting craftsmen or for the process of accumulation.

The system of consumption zones that can be outlined by the finds of the HaA1 period differs from the previous period in many ways, since the primary zone effecting Transdanubian bronze trade developed in South Transdanubia; in a region that had not maintained a significant relation with the primary consumption zones during the previous period. It is characteristic of all primary consumption zones that tools covered the largest area, which was followed by the consumption zones of weapons and ornaments. Within the three zones all functional groups focus on the same region, which determines the central part of the primary bronze use zones. During the HaA1 period Eastern Transdanubian communities were situated in the secondary consumption circle. Taking the groups of weapons and tools into consideration, these communities also connected to the Southland Urnfield culture with numerous links. However, on the basis of ornament wearing customs - which show the picture of a closed system- the material and spiritual culture of the South Transdanubian region had the greatest effect on the settlements of the Mezőfold.

During the HaA1 period the consumption zones, which were maintained by the Transdanubian armed elite, included three graphs with different structures. Firstly the short but numerous links of tools and ornaments, secondly the network of weapons consisting of longer links, and also covering secondary consumption zones, and thirdly the system of occasional links of prestige goods connecting long distances. It can be determined by the three distinct levels of organisation showing equal, increased centrality that the consumption zone - that had developed in connection with the weapon use practices of the elite - also affected the use circle of tools. However, contrary to weapons, tools moved through short distance networks organized on the level of households. The primary consumption zone of large-sized 
sheet artefacts, which also belong to prestige goods, as well as of weapons and heavy tools is equal. Based on all of these observations: the accumulation of bronze in large number, the organisation of production, the control of craftsmen/workshops and the possession of prestige goods can be connected to the armed elite.

During the HaA2 period all the primary consumption zones of the Kurd horizon disappear. New centers develop in the northern part of Transdanubia, of which small territorial extenstion, isolation, and the absence of weapons is typical. The catchment area of the Northern Mezőföld and the Velence Hills is an active part of the Northeast Transdanubian region; however, it proves the isolation of these zones that no assemblage is known from this period south of the Velence Hills. Even unique finds are only scattered along the Danube. With regards to Transdanubia: assemblages with small number of finds decreased among hoards, and instead unique finds and depots accumulating many bronze items occurred in a large number.

According to the analysis of the Transdanubian finds none of the three main functional groups of the HaB1 period of the Great Hungarian Plain appeared as a closed set. The primary consumption zone of tools can be located to two separated areas; to the central and upper sections of the Tisza River. In contrast to the previous periods no large-area secondary consumption zone developed in the eastern part of Transdanubia, but tool types of the Great Hungarian Plain and their imitations appear in small, isolated microregions. Producing weapon imitations is the only form of appearance of the demand for prestige among the early Urnfield communities of Eastern Transdanubia.

The complete reorganization of the social and economic background of the later Urnfield culture can be assumed behind the change of deposition customs. Together with the disappearance of deposition methods yet frequent in the earlier period and connected to individuals and households, the practice of single burials and tumulus burials of small communities also disappeared. Instead of them depots with large number of artefacts appeared, and the formation of cemeteries with hundreds of graves still in use during the HaB1-B2/3 period began. The building of fortifications started at the same time with the consolidation processes observable in depositions and burials indicates that the representational need of the elite transformed, and a kind of isolation and centralization began. The primary environment of these processes was provided by fortified settlements. Their building, maintenance, possession and sharing became a new form of expressing prestige during the closing phase of the Urnfield period.

Based on the analyses of functional artefact groups, Eastern Transdanubia can be listed to the secondary and the occasional consumption circle in the HaB2/3 period. The primary consumption area of ornaments developed along the lower riverside of the Vág, the primary zone of tools can be located to the Moravian Basin, while the consumption area of weapons covers the Moravian and Vienna Basin. On the basis of the moulds of the Mezöföld only the costume wearing customs and the local character of manufacturing processes can be determined, but items with indicator role could not be revealed through interaction processes. Accordingly, households or members of the elite establishing interaction networks also remained "invisible".

The primary consumption area of Eastern Transdanubian assemblages dated to the HaB3 period, thus steppean-type horse equipment can be located to the Baranya and Szerémség 
sections of the Danube valley. Hoards found in the Eastern Transdanubian region are closely connected to the deposition practices of the Great Hungarian Plain, on the basis of which the effects of the new material culture can be also demonstrated in the secondary consumption zone. At the same time only unique weapons or some elements of the horse equipment reach the tertiary, peripherical consumption areas, which usually get buried together with mixed hoards consisting of ornaments and tools; thus following characteristic Late Bronze Age deposition practices. Artefacts of the armed elite - weapons, horse equipment and ornaments alike - are known, however, this armed group cannot be placed in a real social or economic environment. Representation only affected men's tool sets, and the finds do not refer to a central consumption area, hence the territorial organization of communities is not similar to that of the Urnfield culture.

To sum up, connection networks reconstructed by the changes in the use of bronze artefacts, the methods of placing them out of use and the traces of prestige visible even on the material culture highlight that the Late Bronze Age of the Carpathian Basin cannot be considered as a coherent system. An interaction network with a symmetrical structure in Transdanubia and the Great Hungarian Plain cannot be demonstrated in any of the periods. This phenomenon can be explained by the different-rate development of the material culture of the two supraregions. Phase delays of the cultural cycles of the two regions were combined artificially, when bronze finds were classified in unified horizons. However, differences between cultural cycles also appear in the form of differences within the material culture, economic system, social conditions and spiritual life of Bronze Age communities. With the above presented statistical methods and network analyses, these phenomena become measurable and comparable.

\section{References}

BRughmans, T. 2010: Connecting the dots: towards archaeological network analysis. Oxford fournal of Archaeology 29, 277-303.

Brughmans, T. 2012: Thinking Through Networks: A Review of Formal Network Methods in Archaeology. Fournal of Archaeological Methods and Theory - Online DOI 10.1007/s10816-012-9133-8, $1-40$.

Drennan, R. D. 2009: Statistics for Archaeologists - A Commonsense Approach. New York.

EvANS, T. S. - Rivers, R. J. - KNAPpetT, C. 2012: Interactions in space for archaeological models. Advances in Complex Systems 15, 1-20.

Falkenstein, F. 2011: Zu Struktur und Deutung älturnenfelderzeitlicher Hortfunde im nordalpinen Raum. In: Dietz, U. L. - Jockenhövel, A. (Hrsg.), Bronzen im Spannungsfeld zwischen praktischer Nutzung und symbolischer Bedeutung. Prähistorische Bronzefunde XX/13. Stuttgart, 71-105.

Furholt, M. 2011: Materielle Kultur und räumliche Strukturen sozialer Identität im 4. und 3. Jt. v. Chr. in Mitteleuropa. Eine methodische Skizze. In: Hansen, S. - Müller, J. (Hrsg.), Sozialarchäologische Perspektiven: Gesellschaftlicher Wandel 5000-1500 v. Chr. zwischen Atlantik und Kaukasus. Archäologie in Eurasien 24. Berlin, 243-267.

Gauthier, E. 2008: Consumption and Circulation of Prehistoric Products in Europe: Characterization of Spatial Evolutions by Using Map Algebra. In: Analysing Ancient Economies and Social Relations. Layers of Perception - CAA 2007. Berlin, 375-383. 
Gosden, Ch. - Marshall, Y. 1999: The Cultural Biography of Objects. World Archaeology 31, $169-178$.

HorejS, B. 2009: Alltagskulturen und Eliten zwischen Karpatenbecken und Ägäis. Verschiedene Kommunikationsmodelle? In: Krenn-LeeB, A. - Beier, H.-J. - Claßen, E. (Hrsg.), Mobilität, Migration und Kommunikation in Europa während des Neolithikums und der Bronzezeit. Beiträge zur Ur- und Frühgeschichte Mitteleuropas 53. Langenweissbach, 197-207.

Kemenczei, T. 1996: Angaben zur Frage der endbronzezeitlichen Hortfundstufen in Donau-Theißgebiet. Communicationes Archaeologicae Hungariae, 53-92.

Köszegr, F. 1988: A Dunántúl története a későbronzkorban - The history of Transdanubia during the Late Bronze Age. BTM Műhely 1. Budapest.

Krause, R. 2008: Bronze Age Hillforts in the Alps. In: Czebreszuk, J. - Kadrow, S. - Müller, J. (eds.), Defensive Structures from Central Europe to the Aegean in the 3rd and 2nd millenium BC. Studien zur Archäologie in Ostmitteleuropa 5. Poznań - Berlin, 65-84.

Levy, J. E. 1979: Evidence of Social Stratification in Bronze Age Denmark. Fournal of Field Archaeology 6, 49-56.

Mozsolics, A. 1985: Bronzefunde aus Ungarn. Depotfundhorizonte von Aranyos, Kurd und Gyermely. Budapest.

Mozsolics, A. 2000: Bronzefunde aus Ungarn. Depotfundhorizonte Hajdúböszörmény, Románd und Bükkszentlászló. Prähistorische Archäologie in Südosteuropa 17. Berlin.

Munson, J. L. - MACRI, M. J. 2009: Sociopolitical network interactions: A case study of the Classic Maya. Journal of Anthropological Archaeology 28, 424-438.

Pydyn , A. 1999: Exchange and Cultural Interactions. A study of long-distance trade and cross-cultural contacts in the Late Bronze Age and Early Iron Age in Central and Eastern Europe. British Archaeological Reports - International Series 813. Oxford.

ŠabatovÁ, K. 2010: Möglichkeiten der statistischen Methoden bei der Auswertung eines bronzezeitlichen Fundorts. In: Horejs, B. - Jung, R. - Pavúk, P. (eds.), Analysing Pottery. Processing-Classification-Publication. Studia Archaeologica et Medievalia 10. Bratislava, 99-120.

Sosna, D. - Galeta, P. - Šmejda, L. - Sladek, V. - Bruzek, J. 2013: Burials and Graphs: Relational Approach to Mortuary Analysis. Social Science Computer Review 31/1, 56-70.

ŢÂRLEA, A. 2008: The concept of 'selective deposition'. Peuce 6, 63-132. 


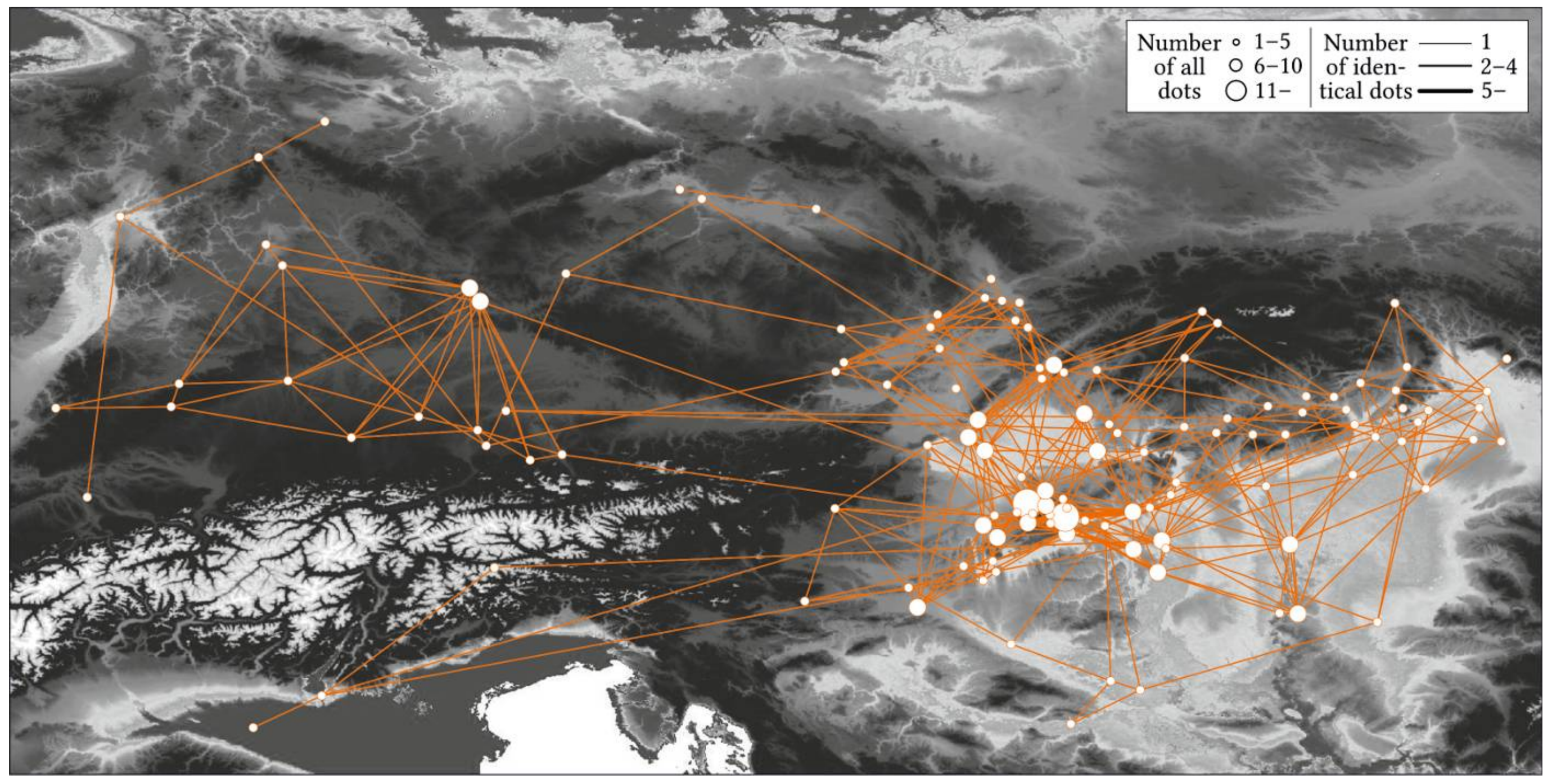

Fig. 8. The simple gravity network of Eastern Transdanubia during the BrD period. 


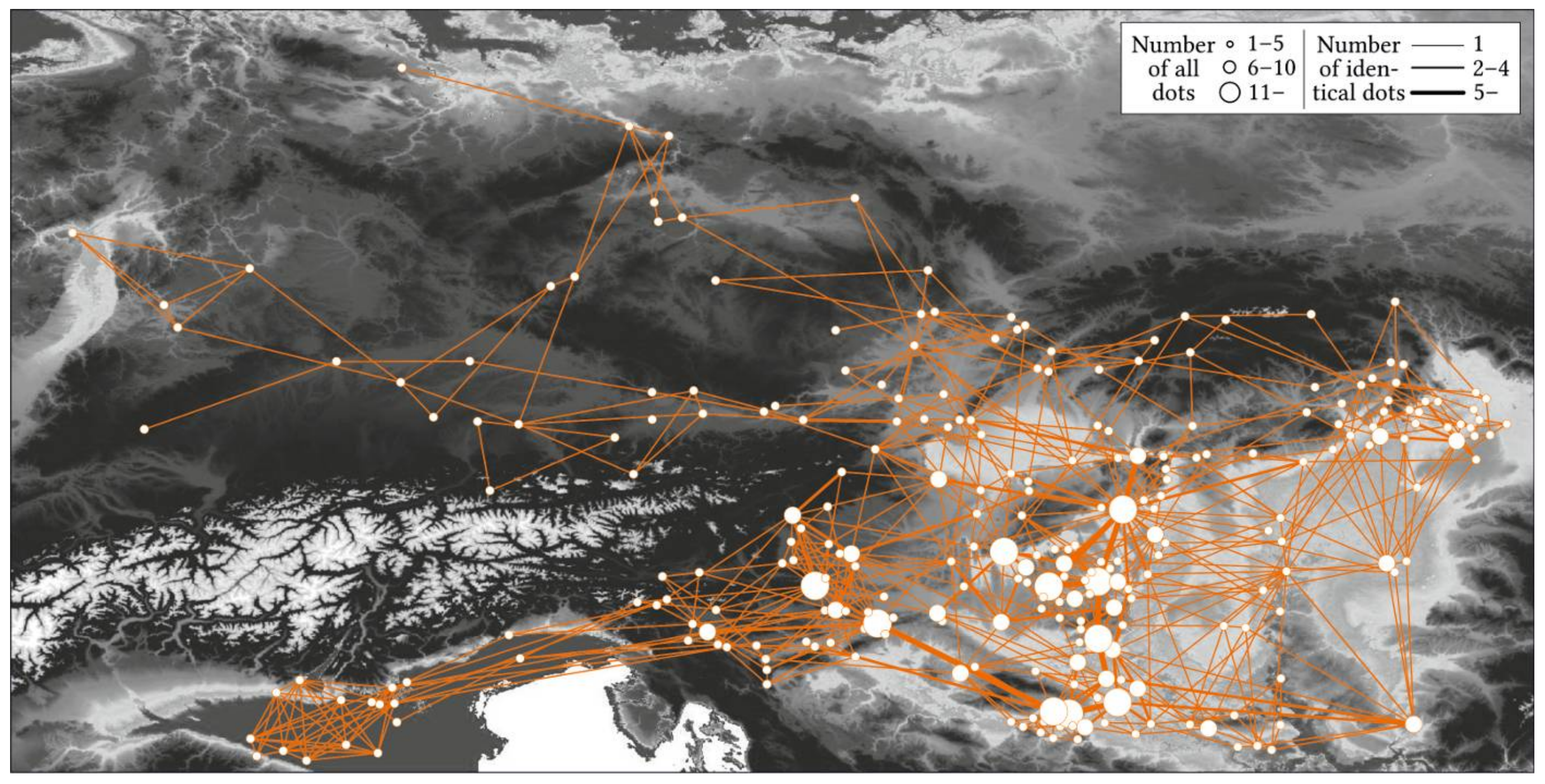

Fig. 9. The simple gravity network of Eastern Transdanubia during the HaA1 period. 


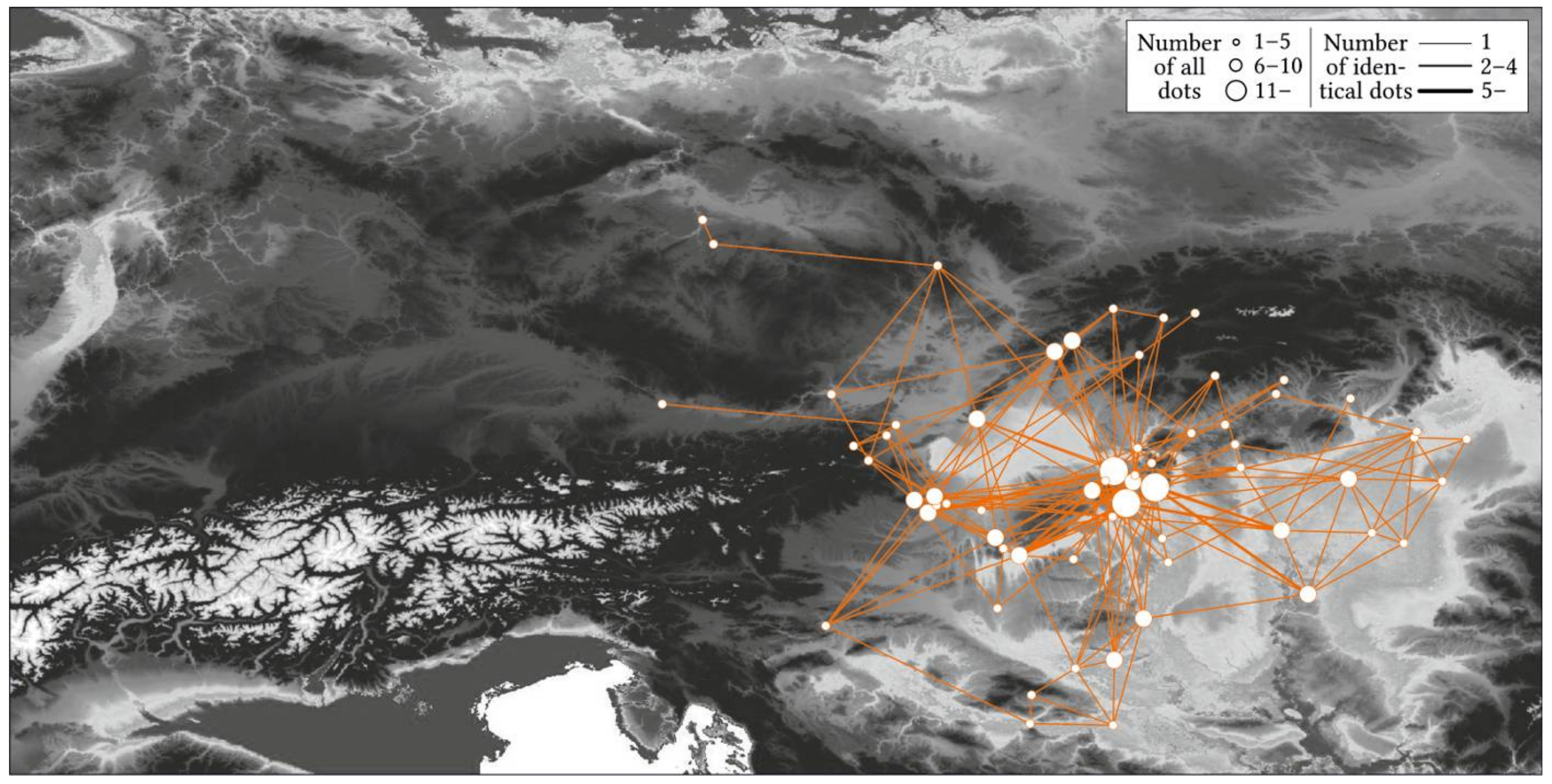

Fig. 10. The simple gravity network of Eastern Transdanubia during the HaA2 period. 


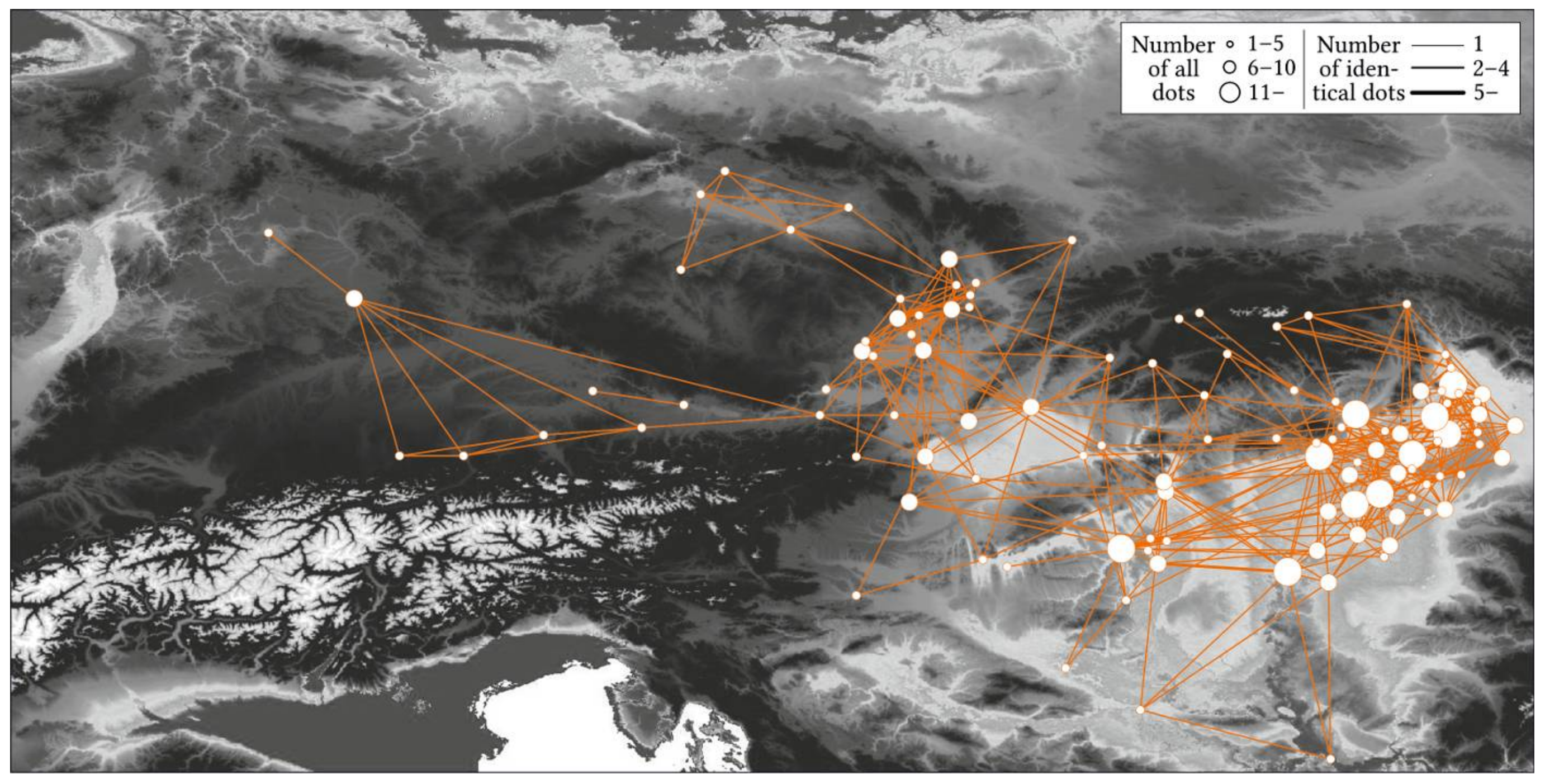

Fig. 11. The simple gravity network of Eastern Transdanubia during the HaB1 period. 


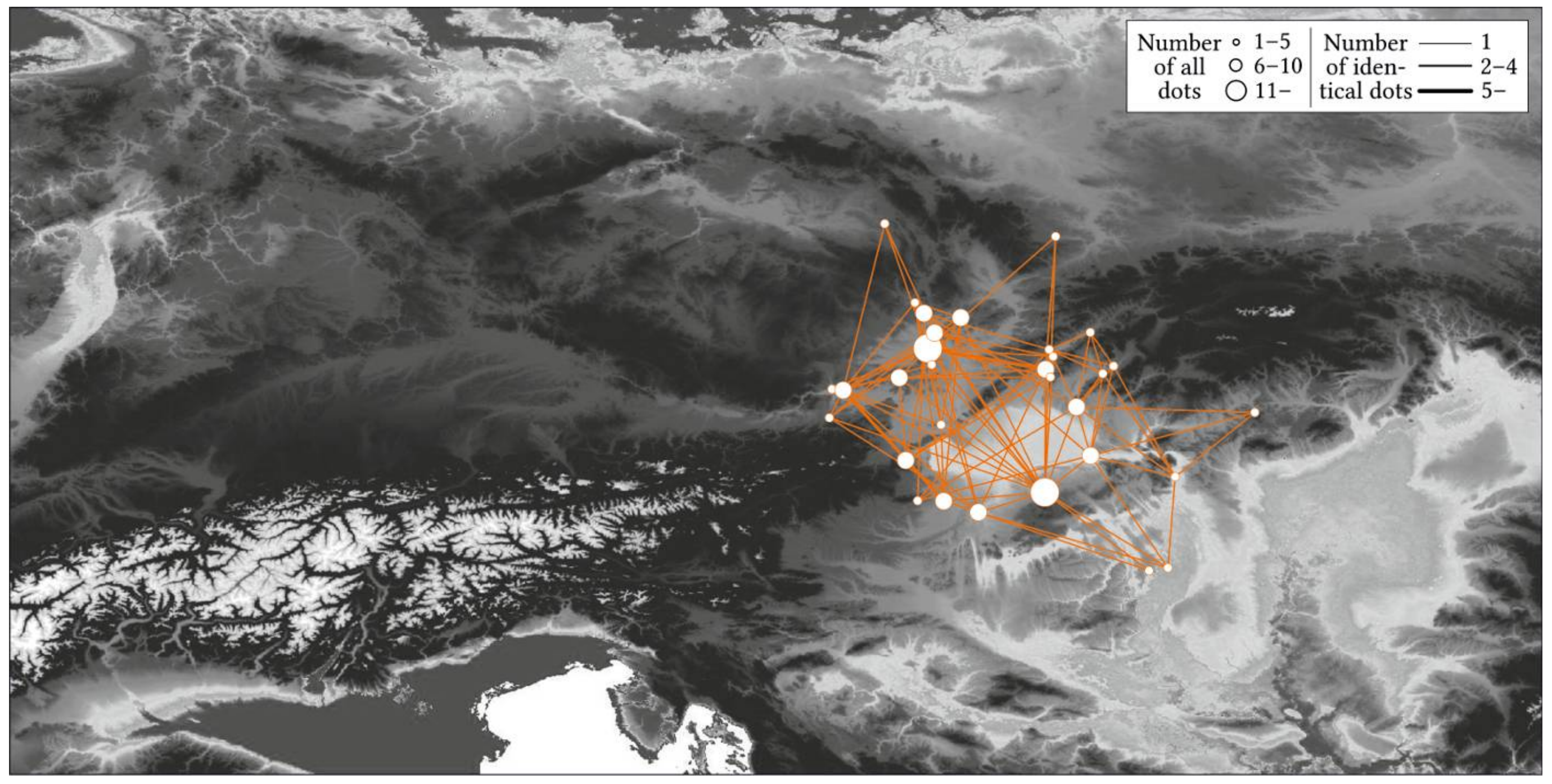

Fig. 12. The simple gravity network of Eastern Transdanubia during the HaB2/3 period. 


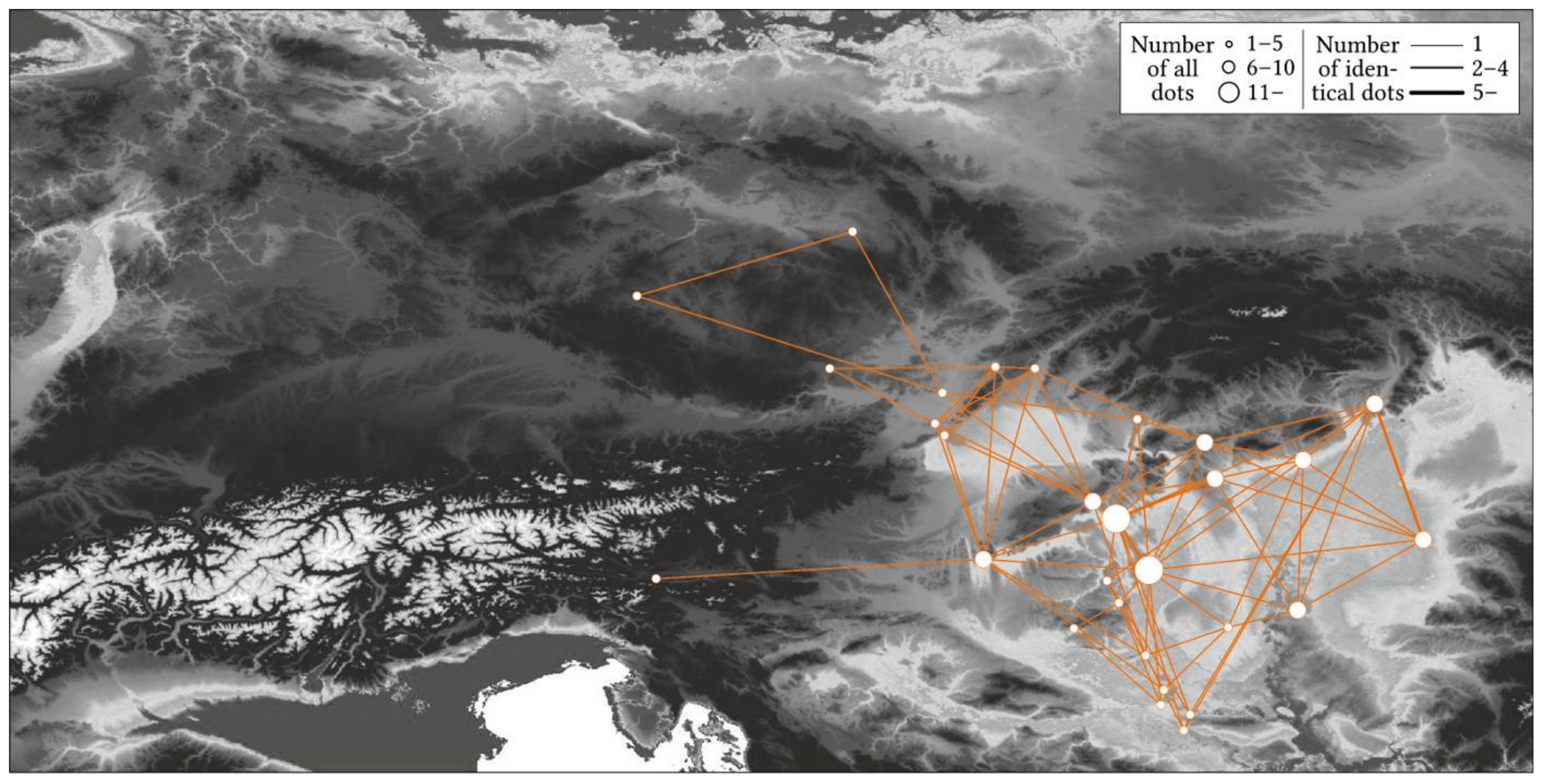

Fig. 13. The simple gravity network of Eastern Transdanubia during the HaB3 period. 